\title{
Effect of Evaporative Cooling Combined with Heat Sink on PV Module Performance
}

\author{
Ibtisam Ahmed Hasan Iman saleh kareem Duha Adil Attar \\ Electro mechanical Engineering Department University of Technology Baghdad, Iraq \\ dr_ibtisam_ahmed@yahoo.com dr_esk_71@yahoo.com engduha_1990@yahoo.com
}

\begin{tabular}{|l|l|l}
\hline Submission date:- 11/4/2018 & Acceptance date:- 16/4/2018 & Publication date:-2/6/2019
\end{tabular}

\begin{abstract}
A pin fins array as a heat sink along with a moist wood wool pad to serve as novel cooling system to cool PV panel has been used. The present cooling system was based on the evaporative cooling concept and extended area of heat transfer. The results gave enhancements in output power and panel's efficiency about $32.7 \%$ and $31.5 \%$ respectively. This improvement in the module performance was attributed to the reduction in the operation temperature of the solar cell. The reduction in module temperature was about $26.05 \%$.
\end{abstract}

Keywords: Evaporative cooling, Pin fins, Extended surface, Pin fin.

\begin{tabular}{|c|c|c|}
\hline Symbol & Meaning & Unit \\
\hline $\mathrm{A}_{\mathrm{B}}$ & The base area of heat sink & $\mathrm{m}^{2}$ \\
\hline$A_{c f}$ & Fin cross section area $\left(\frac{\pi \mathrm{Df}^{2}}{4}\right)$. & $\mathrm{m}^{2}$ \\
\hline$A_{f B}$ & Free surface area of heat sink base. & $\mathrm{m}^{2}$ \\
\hline$A_{\text {fin }}$ & area of outer surfaces of the fin $=\pi D_{f} L_{f i n}$ & $\mathrm{~m}^{2}$ \\
\hline$A_{\text {total }}$ & Outer surface area of heat sink & $\mathrm{m}^{2}$ \\
\hline $\mathrm{Cp}$ & Heat capacity. & $\mathrm{J} / \mathrm{kg} .{ }^{\circ} \mathrm{C}$ \\
\hline ds & The distance between center to center of fins & $\mathrm{m}$ \\
\hline Effect $_{H S}$ & The overall finned surface effectiveness of heat sink & $\mathrm{W}$ \\
\hline $\mathrm{h}$ & Convection coefficient & $\mathrm{W} / \mathrm{m}^{2} \cdot \mathrm{K}$ \\
\hline$h_{c o-H S}$ & Heat transfer Convection coefficient of heat sink & $\mathrm{W} / \mathrm{K} \cdot \mathrm{m}^{2}$ \\
\hline$Q_{h-s}$ & Total heat dissipation from heat sink & $\mathrm{W}$ \\
\hline$k_{\text {fin }}$ & Thermal conductivity of fin material. & $\mathrm{W} / \mathrm{m} \cdot \mathrm{K}$ \\
\hline$\dot{\boldsymbol{m}}$ & Mass flow rate, equal to $\rho_{V A_{c h s}}$ & $\mathrm{Kg} / \mathrm{s}$ \\
\hline $\mathrm{Re}_{\mathrm{s}}$ & Reynolds number $=\mathrm{Vs} / v$. & \\
\hline$R_{H S}$ & The thermal resistance of heat sink. & $\mathrm{K} / \mathrm{W}$ \\
\hline $\mathrm{S}$ & Channel width between fins rows or columns $=d s-D_{f}$ & $\mathrm{~m}$ \\
\hline$P r_{\text {film }}$ & Prantle number at film temperature. & \\
\hline$T_{B}$ & Base temperature & $\mathrm{K}$ \\
\hline$T_{\mathrm{am}}$ & Ambient temperature & $\mathrm{K}$ \\
\hline$N_{f}$ & The total number of fins & \\
\hline$\eta \_$fin & Fin efficiency & \\
\hline П_HS & Heat sink efficiency & $\mathrm{W}$ \\
\hline
\end{tabular}




\section{1-Introduction:}

Photovoltaic cell performance influences by its temperature in a negative manner due to the negative coefficient of temperature of crystalline silicon [1].It had been estimated that the temperature coefficient about -0.4 to $-0.5 \% \mathrm{~K}-1$. This leads to a decrease the cell's efficiency, which is typically about $15 \%$ under a standard test condition (at temperature of $25^{\circ} \mathrm{C}$ and irradiance of $1000 \mathrm{w} / \mathrm{m} 2$ ), [2]. The operating temperature of the cell increases because a small part of the solar irradiance only convert to electricity and a large part of radiation is absorbed as a heat by the panel.The heat accumulation in the panel causes the efficiency to be decrease.The increasing temperature may be partially avoided by extracting heat using a suitable cooling system. Where, a lot of cooling methods were developed and reported in previous literatures. In the passive cooling methodologies there are a lot of works. Such as in Gotmare et al [3] and Cuce et al [4] utilized a passive fins cooling method under natural convection to raise the PV panels performance. Fins of different cross section with perforation were linked at the back surface of the panel. Cătălin et al [5] presented a numerical approach for reducing photovoltaic panels temperature using heat sinks that cooled by air. A heat sink has been conceived as a ribbed wall. Others used another passive method. They took advantage of from the heat of liquid evaporation as in Ref [6]. They had been developed a simple passive cooling system using cotton wick structures at the rear side of PV module. The electrical and thermal performance of module with cooling system, which was consisted from cotton wick structures, has been tested. Using of the water, $\mathrm{CuO} /$ water nanofluid and A12O3 /water nanofluid as a cooling fluid were investigated experimentally. And Ref [7] developed a passive cooling system using a water absorption towel which fixed it on the rear side of a PV panel then, maintain moist condition via dropping a little amount of water. Hasan et al [8] investigated a passive cooling system by attaching a cellulose pad at the rear surface of photovoltaic panel and maintained wet condition by flowing drops of water through cellulose pad. The pad has been saturated with water continuously. The evaporation of water from the wet surface (pad) caused a significant effect in the PV panel performance.

Workers in this field are always looking for the best cooling methods. The cheapest and easiest method for removing the excess heat from PV panel is the natural air circulation but it has a low effectiveness. An extended area (fin) as a heat sink may be used to enhance the activity of cooling by natural air. Also, the performance of fins as a heat sink can be enhanced by combining a simple passive cooling system which is based on an evaporative cooling technique, which is the current research trend.A new cooling arrangement has been designed and tested in the present work. It is fabricated from a pin fins array as a heat sink and combined with a moist wood wool pad to be fixated at rear side of PV panel to achieve the better performance of PV panel through providing appropriate cooling conditions.

\section{Mathematical Model of Heat Sinks}

For simple analysis, it was supposed to be one dimensional heat flow model in finding equal resistance since it just works with one heat source.

The thermal resistance of heat transfer for both heat sink and the surroundings be found by equation which has been adjusted by Ref. [9]. The equation is involving with the internal thermal conductivity resistance from the fin material with the resistance of heat transfer by the convection of outside fins surface and free base area. At finned surface, the radiation losses and resistance will be ignored due to the temperature decline from roots to the tips of the fins [10]. The surface of the heat sink will be subjected to a little temperature varsities to the surroundings as a result of the fins influence. All these suppositions made by the laboratory conclusions were accomplished by Ref.[11] [12] that led up to modify Corominas's formula [13] to be as follows :

$$
Q_{h-s}=\left(h_{c o-H S}\right) \cdot\left(A_{f B}+\mathrm{\eta}_{f i n} N_{f} A_{f i n}\right)\left(T_{B}-T_{a m}\right)(1)
$$

The thermal resistance of heat sink is, [14]:

$$
R_{H S}=\frac{Q_{h-s}}{T_{B}-T_{a m}}=\frac{1}{\left(h_{c o-H S}\right) \cdot\left(A_{f B}+\mathrm{\eta}_{f i n} A_{f i n}\right)}+\frac{1}{2 \dot{m} c_{p}}(2)
$$

And the total heat dissipation is:

$$
Q_{h-s}=\frac{\left(T_{B}-T_{a m}\right)}{R_{H S}}(3)
$$


Equation 1 has been involved fin efficiency in order to compensate the variation of temperature along the fin without an affecting in the equation linearity and to moderate the effect of the temperature variation along fin surface [13].

The aim of this thermal analysis is to determine the heat sink thermal performance and optimum fin dimensions and spacing to choose the suitable shape that it can be manufactured easily. In the present work, a heat sink with a cylindrical pin fins will be considered in the analysis of the proposed model, as shown in figure (1). The cylindrical-shaped pins have the better heat transfer coefficient value than other pins shapes because there is a weak recirculation flow among them and give a share to contribute a fresh air in heat transfer. Pin-fin technology is classified as the most interesting methods for enhancing the exchange of heat [15] Heat sink with pin fin is extensively utilized because of it's not sensitive to the direction of air flow [16]. The pin fins arrangement are considered to be with uniform spacing (Z/D = $\mathrm{X} / \mathrm{D}=2.5$ ) which has been tested by ref [17] to be one of the best fins arrangements.

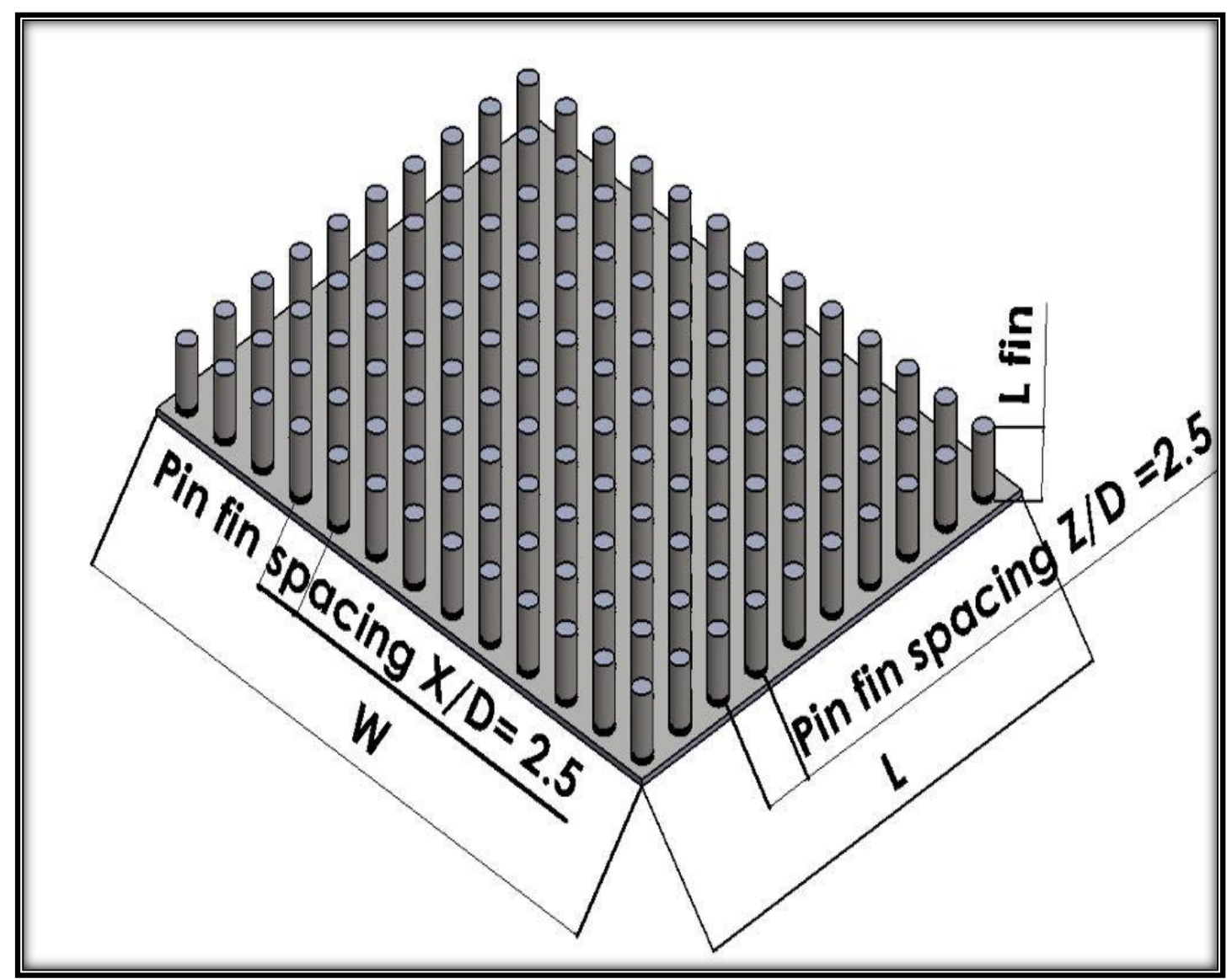

Fig.1. Description of pin fin array (as a heat sink) geometry.

The convection coefficient $\left(h_{c o-f}\right)$ for heat sink with pin fins in-line array arrangement, with Z/D $=\mathrm{X} / \mathrm{D}=2.5$ can be defined as, [17]:

$$
h_{c o-H S}=\frac{0.068 R e_{s}^{0.733} \operatorname{Pr}_{\text {film }}^{0.4} \cdot k_{f i n}}{S}
$$

The total fins number is:

$$
N_{f}=\frac{\mathrm{A}_{\mathrm{B}}}{d s^{2}}(5)
$$

The free area of the base $\left(A_{f B}\right)$ is:

$$
A_{f B}=\mathrm{A}_{\mathrm{B}}-N_{f} \mathrm{~A}_{\mathrm{cf}}(6)
$$

Heat sink thermal efficiency ( $\left.\eta \_H S\right)$ will be calculated as following [18]: 


$$
\begin{gathered}
\eta \_\mathrm{HS}=1-\frac{A_{\text {fin }}}{A_{\text {total }}}\left(1-\eta \_ \text {fin }\right)(7) \\
A_{\text {total }}=A_{f B}+A_{f i n}(8)
\end{gathered}
$$

The overall finned surface effectiveness can be expressed as follows:

$$
\text { Effect }_{H S}=\frac{Q_{h-S}}{h \mathrm{~A}_{\mathrm{B}} \Delta T} \ldots(9)
$$

The suggested design algorithms are programmed by using MATLAB program Functions. Figure (2) presents the flowchart of thermal performance calculations of proposed model with heat sink.

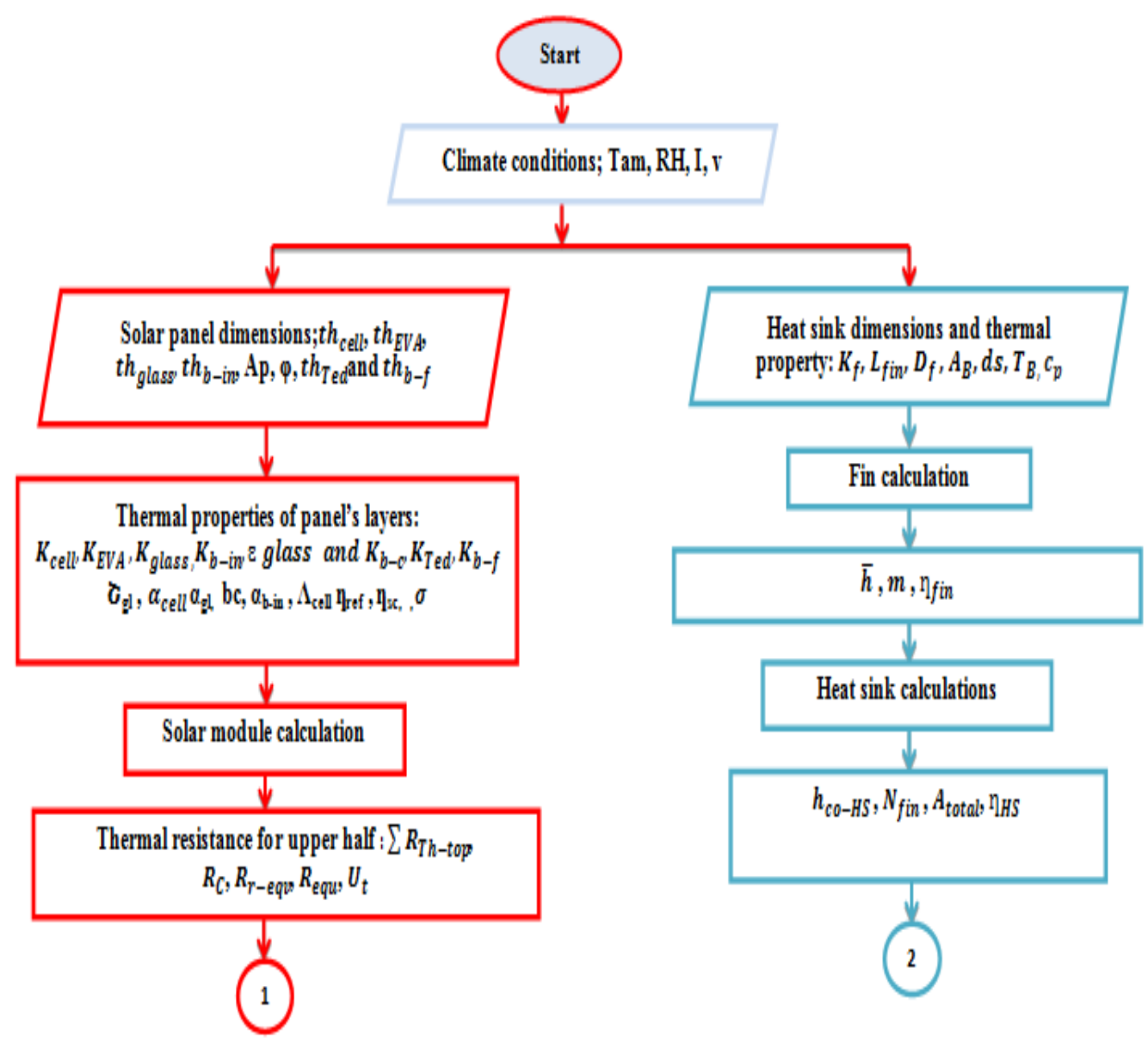




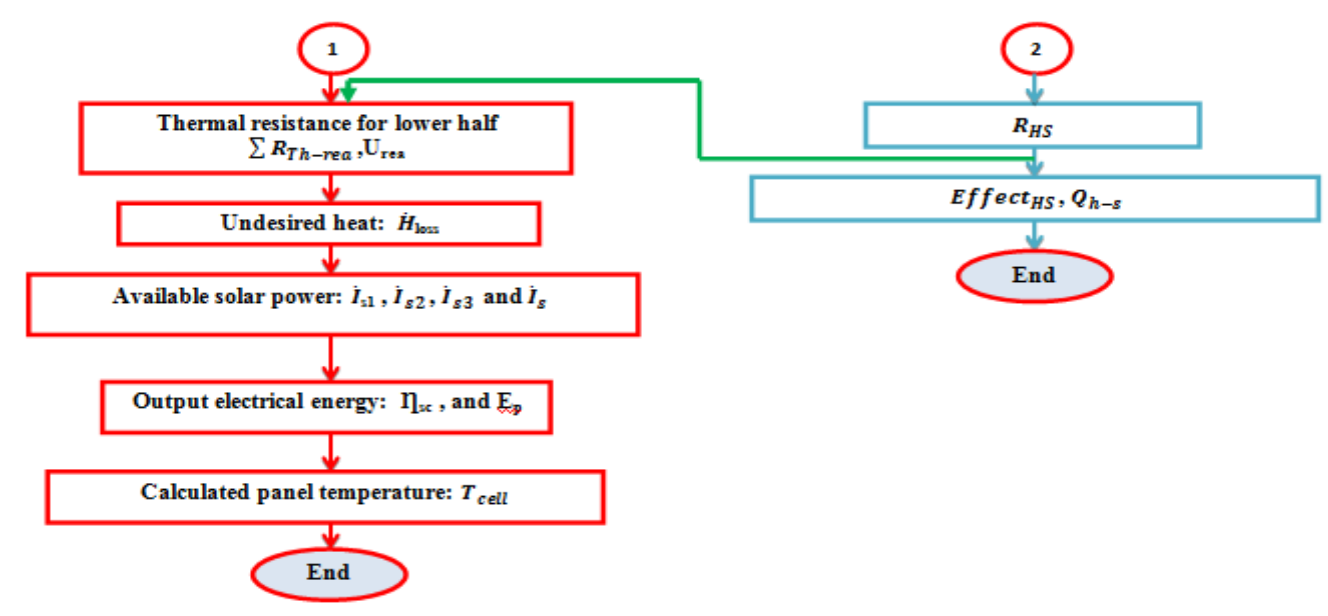

Fig. 2 .The flowchart of thermal performance calculations of proposed model along with heat sink.

\section{Experimental setup:}

The experimental setup composes of a PV panel, a digital multimeter (typed830D+ ) to measure the panel output (current and voltage), a twelve channel recorder (model BTM-4208SD), wood wool pad, heat sink, charge controller( type LM2596 DC-DC HW- 411)connected to $12 \mathrm{~V}$ battery, measurement devices and a water tank, see figure 3. Solar radiation was measured at the same level of the solar panel, using a solar meter (A TES 1333R pyranomete).The temperatures of PV modules were obtained by using k-type thermocouples which connected to the data recorder. Wind speed (by usinga kaindl wind master 2 type), ambient temperature and relative humidity (using Digital meter sensor type UNI-T UT332) were also measured.

The used PV panel (type JP 01) was made from poly-crystalline PVsolar cells. The peak voltage $(\mathrm{Vm})$, peak current $(\mathrm{Im})$ and maximum power $(\mathrm{Pm})$ of it are $17 \mathrm{~V}$,

$0.59 \mathrm{~A}$ and $10 \mathrm{~W}$ respectively and its dimensions are $285 \mathrm{~mm}$ and $350 \mathrm{~mm}$. The solar cells is arranged in 8 rows and 9 columns. The heat sink was made of an aluminum alloy and it was manufactured manually. Thermal conductivity of the aluminum alloy was $123.84 \mathrm{~W} / \mathrm{m} . \mathrm{K}$. The heat sink selected for experiments are aluminum alloy sheet with dimensions of $320 \mathrm{~mm} \times 245 \mathrm{~mm} \times 3 \mathrm{~mm}$, and 130 cylindrical shafts (as fins) of $10 \mathrm{~mm}$ diameter and $50 \mathrm{~mm}$ length with pin fins spacing $2.5 \mathrm{D}$ which was used depending on the conclusion of Ref [17]. Heat sink pattern was fabricated by drilling 130 holes on the baseboard of heat sink with $3 \mathrm{~mm}$ depth in order to install the fins. The holes and fins were distributed according to the thermal modeling results.Rods (fins) were inserted in the holes tightly in order to achieve a good contact between fin and holes surface with rear surface of panel. The back side of heat sink has been smoothed very well. And then the heat sink has been attached at the rear of the PV panel using thermal adhesive. While, moist wool wood pad was carefully placed on the rear to be completely in touch with the rear surface of the heat sink, see figure (3). 


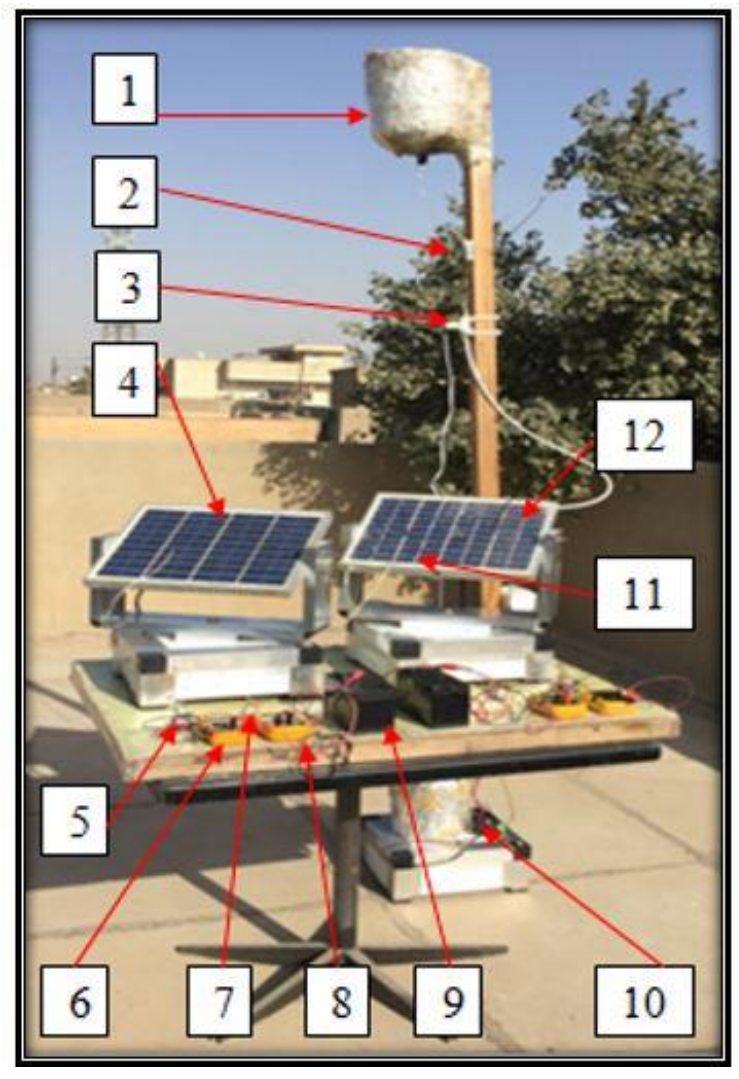

(A)

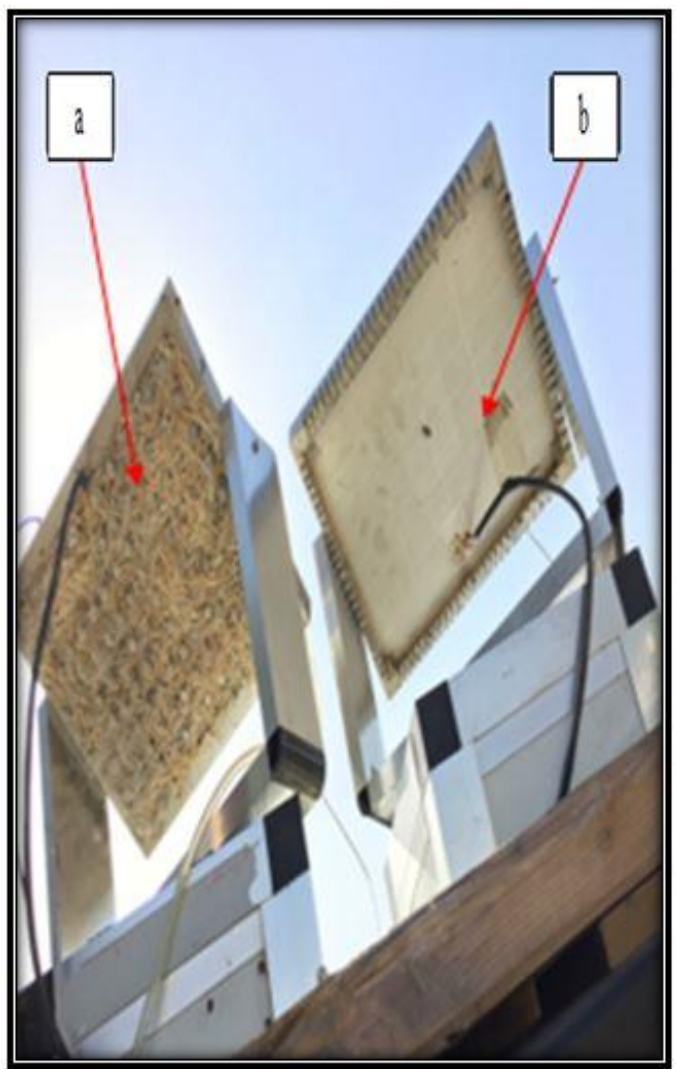

(B)

Fig. 3 .Experimental setup pictures.

(A) [1-Supply tank 2- regulated valve 3- supply hosepipe 4-front view standalone panel 5- Load 6- Digital multi-meter(as Ammeter) 7- Voltage regulator 8- Digital multi meter(as Volt meter)9- Battery type ( SLA 12V *9AH ) 10- Storage tank 11-thermocouple 12-front view panel with wood wool ], (B) [ a- panel without cooling b- panel with cooling ].

Two same types of PV panels (Polycrystalline solar cells) have been used to implement the proposed PV cooling system to be as a standalone PV panel and panel along with heat sink companied with moist pad, as shown in Figure (3). In order to achieve the moist condition for pad, the water was dropped continually and the mass flow rate of water has been adjusted using regulated valve which was fixated inside the supply hose, see figure (3). The water is dripping to the wood wool pad to extract the undesirable heat through a perforated pipe. A plastic pipe with diameter of $5 \mathrm{~mm}$ used to distribute the water through small perforations along it. The perforated pipe was fixated at the upper edge of the back surface of the module and connected to the supply hosepipe at one end while, the free end was closed. Panels were installed to face the south with an inclination of $31.2^{\circ}$ [19] which were adjusted in order to optimize the collectible solar radiation. Calibrated thermocouples (type K) were utilized to measure the average temperature of panels which was directly monitored by Data Recorder. Ambient temperature, irradiation, wind speed, and relative humidity, output current and voltage with panel's temperature were recorded every twenty minutes. Experiments were carried out during hot weather days in July from 9:00 am to 4:00 pm. All mentioned variables have been recorded at Baghdad of $33.33^{\circ} \mathrm{N}$ latitude and $44.39^{\circ}$ E longitude.

\section{Results and discussion}

\section{I- Thermal Modeling Optimization for Heat Sink}

For optimum design, pin fins spacing were determined to be $2.5 \mathrm{D}$. So, the fins number in heat sink is determined in specific area (the base area of heat sink) according to this assumption along with the fin's diameter. There is a linear relation between the number of fins and fin diameter. To investigate 
the impacts of the fin dimensions on the heat dissipation, effectiveness, and efficiency and overall thermal resistances of heat sink, the fin diameter (or fin numbers) along with the length have been changed in the simulation program from $3 \mathrm{~cm}$ to $7 \mathrm{~cm}$ with an increment of $1 \mathrm{~cm}$ and the diameter from $0.4 \mathrm{~cm}$ to $1.9 \mathrm{~cm}$ with an increment of $0.3 \mathrm{~cm}$ as presented in Figures (4, 5,6 and 7) respectively.

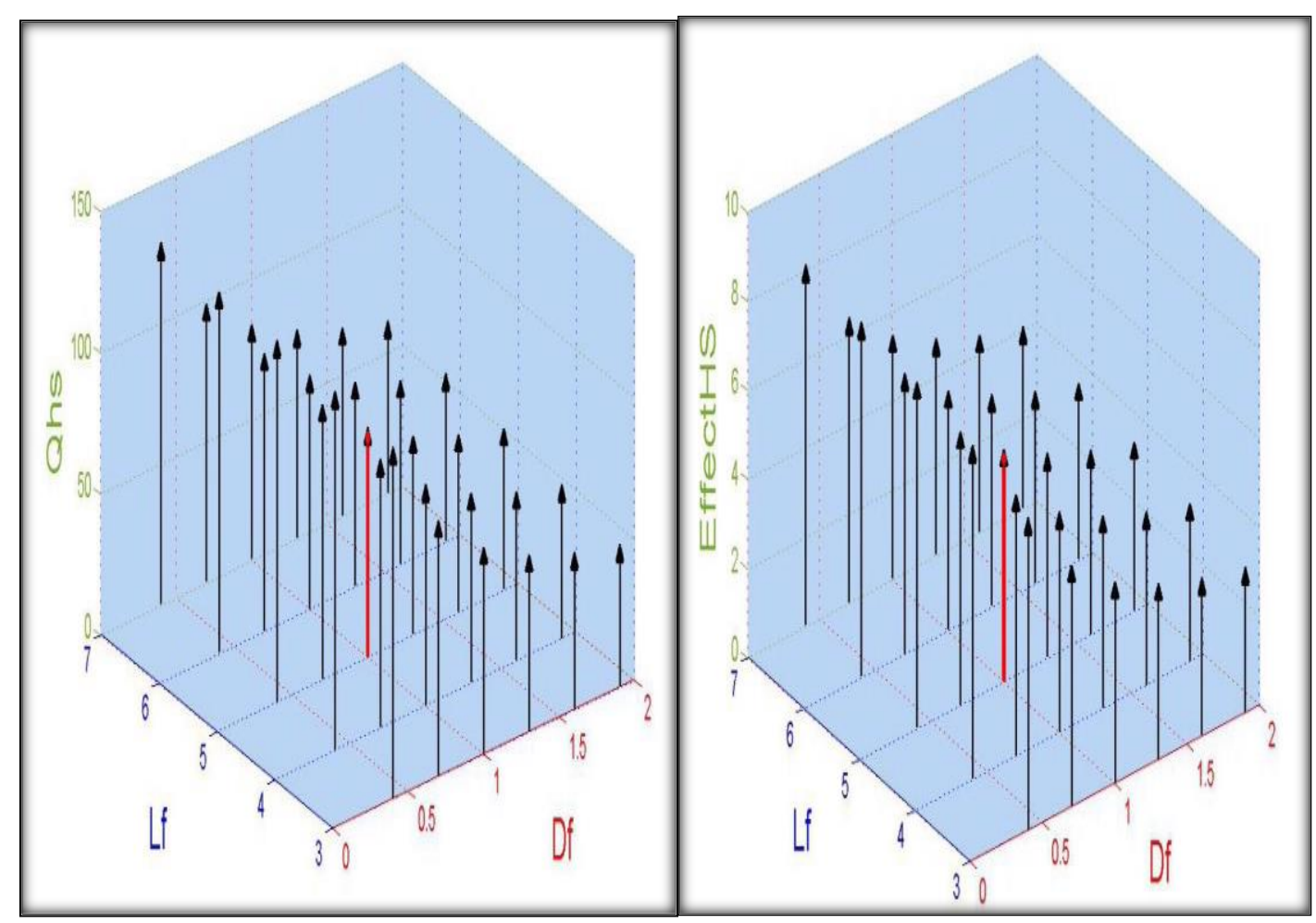

Fig. 4 .Heat dissipation variable Fig. 5 .Heat sink effectiveness

vs fin vs length and diameter.fin length and diameter.

With increasing, the fin diameter from $0.4 \mathrm{~cm}$ to $1.9 \mathrm{~cm}$, the effectiveness and the thermal dissipation is gradually decreased as shown in Figure (4 and 5). But the efficiency of heat sink increased as shown in Figure (6) with increased fin diameter. The effects of the fin length on the heat sink thermal performance were studied as seen in Figure (4, 5 and 6).Usually, the increasing in the fin height will improve the thermal dissipation as well as the effectiveness as shown in Figure (4and 5).And, with fin length increasing from $3 \mathrm{~cm}$ to $7 \mathrm{~cm}$. 


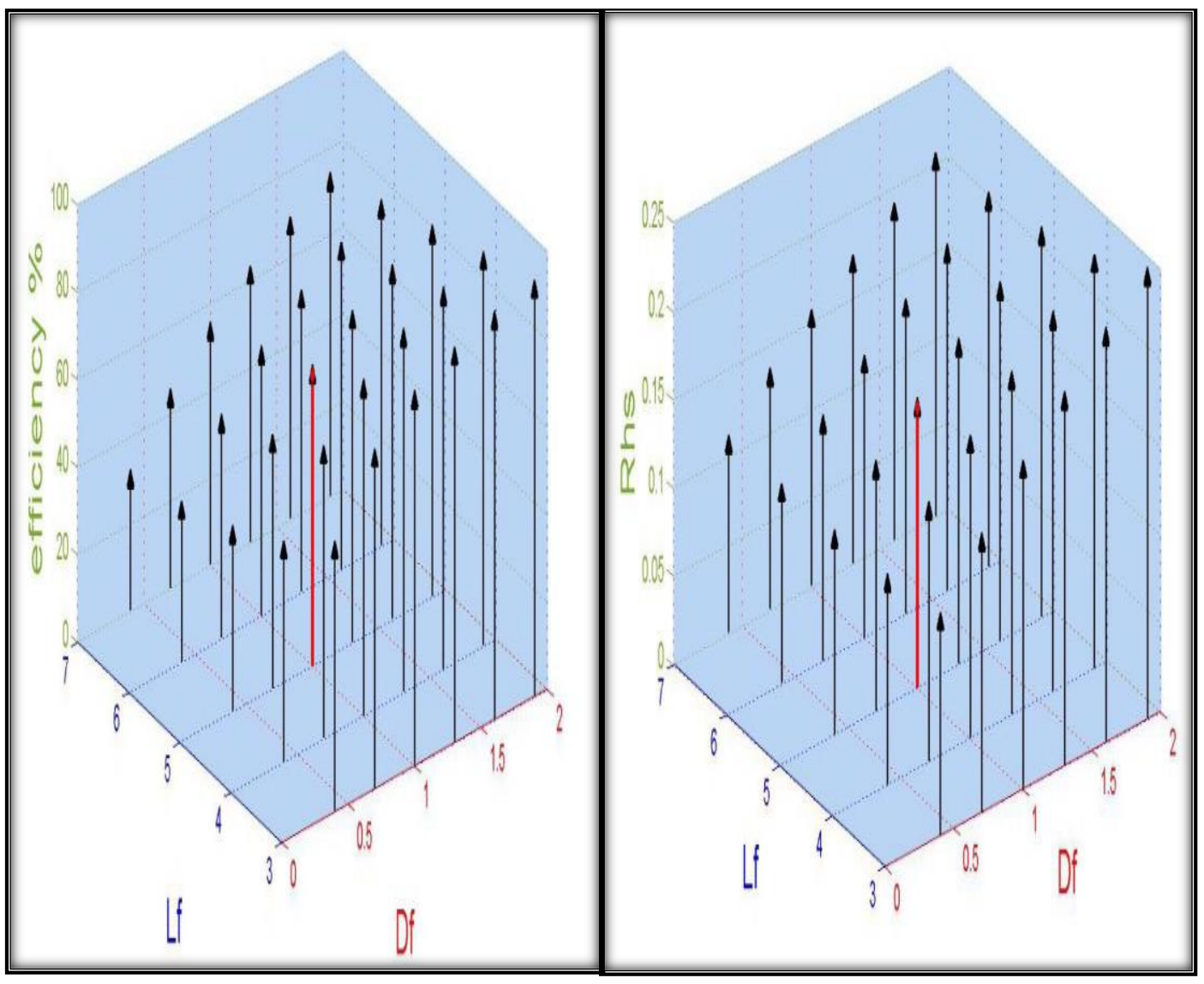

Fig. 6 .Heat sink efficiency

Fig. 7 .Overall thermal resistances vs

\section{Fin length and diameter}

. vs fin length and diameter.

The efficiency of heat sink decreased gradually in a slightly decreasing trend slope as shown in Figure (6). Within the current selected dimensions of fin length, it was found a little effect in the heat sink thermal parameters as shown in above Figures as well as Figure (7). Which represents therelation between overall thermal resistances of the heat sink with the variation of length and diameter of fin. Higher fins are useful to increase the area of heat dissipation but, too high fins will cause in increasing the mass of the heat sink. Therefore, the suitable length should be considered in the actual design. At the practical design, fins with small diameter will be hardly fabricated because the small diameter means a large number of thin fins at a specific area (the base area). Moreover, the small diameters will be easily fractured at the manufacturing process. Considering the cost and easily fabrication of the system, the length, diameter and base thickness of fins are designed to be $5 \mathrm{~cm}, 1 \mathrm{~cm}$ (number of fins 130), and 0.3 $\mathrm{cm}$, respectively. These dimensions will be used as a PV cooling model in current work and they are represented in above Figures in red marker.

\section{The Effect of the Proposed Cooling Methods on Module Performance:}

The comparisons between performances of modules at two operation conditions, (with and without cooling) vs. time were represented in Figure (8, 9, 10, 11 and 12). 


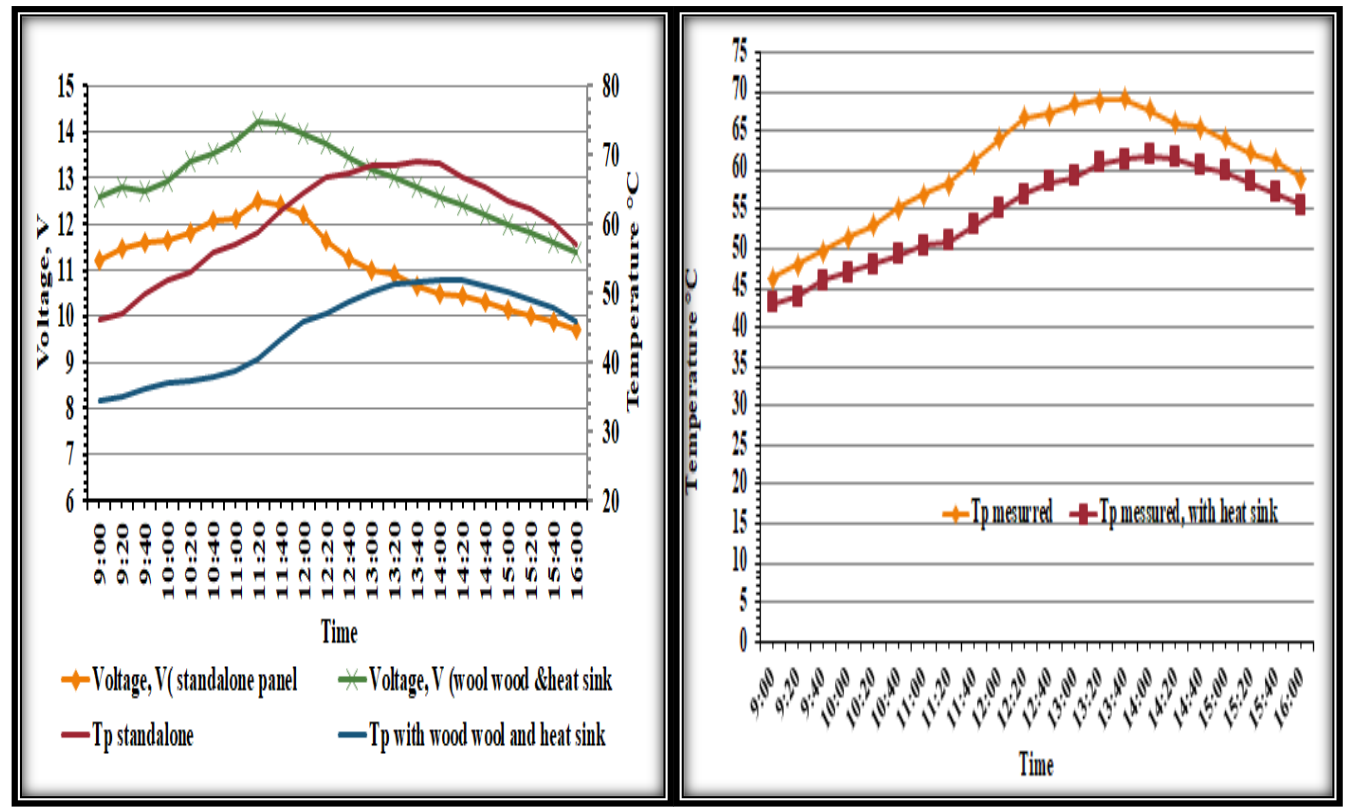

Fig. 8.Panel temperatures vs time.

Fig. 9. Output voltages along

With panels temperatures vs time.

Figure (8) shows that the temperature distribution profiles of solar panel were almost having the same tendency for different cases (without and with cooling). This detects the reliable performance of the solar panel with different operation conditions. Also, it can be observed that the highest module temperature occurred at a period between 1:00 and 2:00 PM which will be called the peak time. For the PV panel temperature without cooling, as shown in Figure (8), a highest temperature has been recorded during the time of experimentation with a maximum temperature about $69.5^{\circ} \mathrm{C}$ at peak time. the effects of using combined cooling system (moist wool wood pad and heat sink) on the thermal performance of solar panel achieved best results by reducing the average panel temperature about $15.8^{\circ} \mathrm{C}$ which is corresponded to a reduction in average module temperature about $26 \%$ compared with the standalone panel temperature. This improvement is attributed to the moisture condition which prevailing at the rear side of the module. The use of water in cooling system always causes a significant improvement in the panel performance due to the high heat capacity of water. Figures (9and 10) show the effects of the proposed cooling systems on both output voltage and current of the modules with time. The use of heat sink with moist pad as a cooling systems achieved an improvement in daily average of output currents about $15.9 \%$ and outputted voltages about $17.76 \%$, compared with the standalone panel output. The improvements are occurred due to the reduction in PV temperature. The amount of solar irradiance determines the amount of output current and the operating temperature of solar panel affects in the output voltage (V). 


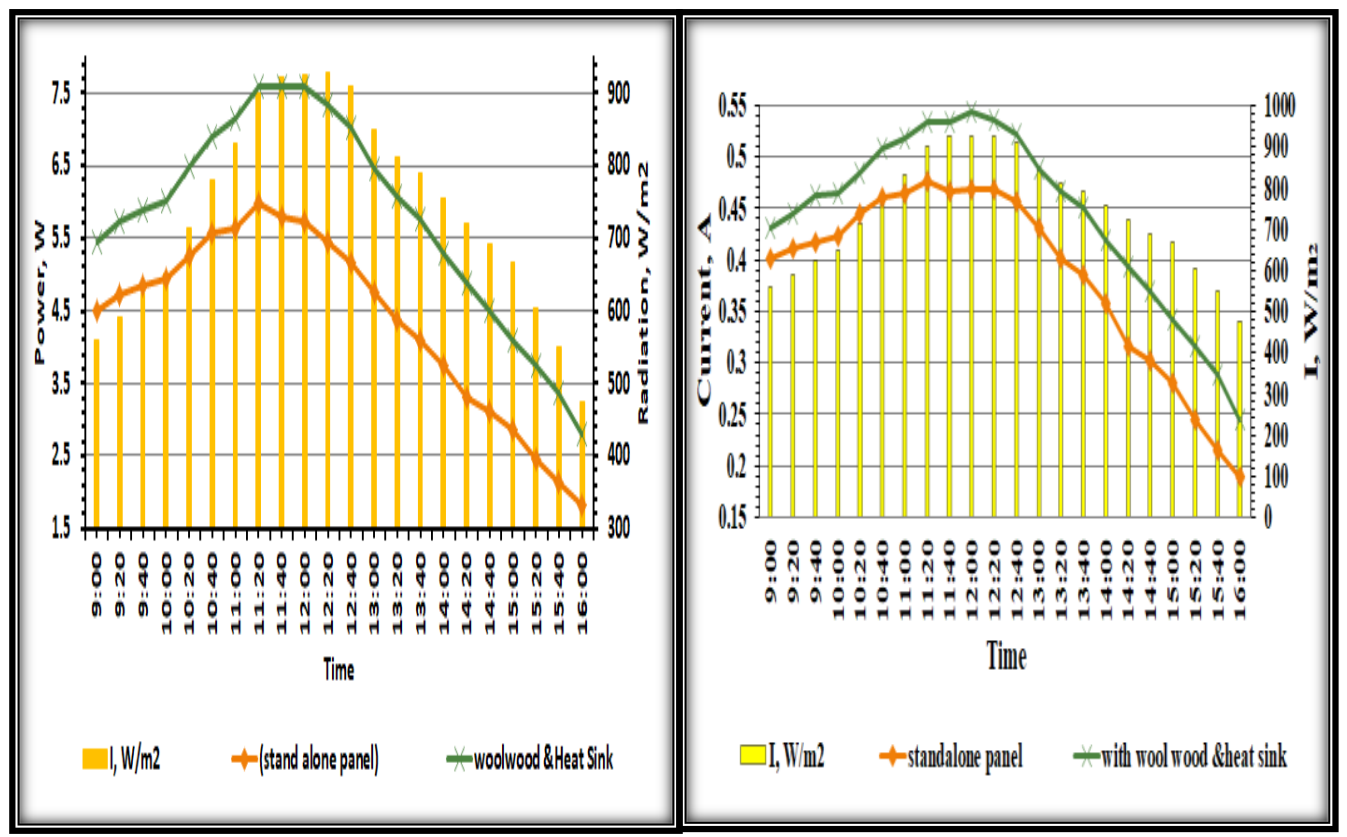

Fig. 10 .Output current along with

Fig. 11 .Output power

Solar radiation vstime. along with solar radiation vstime.

Figure (11) presents the variation of the output power with time for module at different cooling condition along with radiation data. It shows that the output power for the panel without cooling arrangement (standalone) is the least at a value about $4.37 \mathrm{~W}$, while, the output power for the PV panel with cooling system is $7.58 \mathrm{~W}$, that is attributed for using water, which has a high heat capacity. The daily average enhancement is $32.73 \%$.

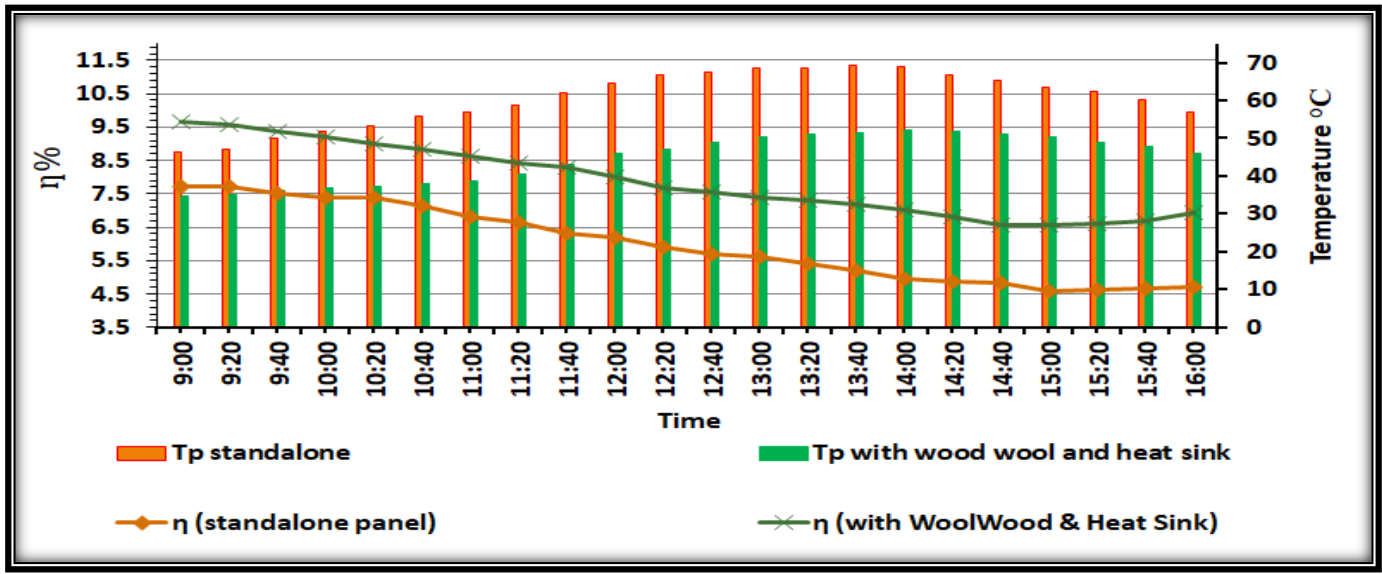

Fig. 12 .PV module efficiency along with panel temperatures vs time at different operation conditions.

The variation of solar module efficiency with the time at different cooling conditions is presented in figure (12) along with the module operation temperatures. The average efficiency is the smaller at a value $6 \%$ without cooling. The panel efficiency has been enhanced about $31.54 \%$ at using moist pad along with heat sink. The experimental results point out that the solar panel temperature has a significant influence on the efficiency and output power of PV module or, the rising of PV module temperature leads for decreasing the output power followed by a reduction in electrical efficiency of PV module.

\section{5- Conclusion:}

A passive cooling system of a wood wool along with heat sink structures isinvested for standalone PV modules to minimize its the temperature, to increase the module output power and 
therefore increasing the efficiencyas well as reducing the thermal degradation rate for the PV panel. The following conclusion remarksare extracted from the current work:

1- It is noted that the PV module temperature without coolingis always higher than the surrounding temperature throughout the operation timewith a maximum temperature about $70^{\circ} \mathrm{C}$ and average temperature about $61^{\circ} \mathrm{C}$ during the date of experiment .

2- The average PV module temperature is decreased to about $45^{\circ} \mathrm{Cwhen}$ using cooling system, which is corresponded to about $27 \%$ reduction for module temperature. It was attributed to the prevailing moist condition on the rear side of module, while the output power and efficiency enhanced about $32.7 \%$ and $31.7 \%$ respectively.

3- The design optimization of heat sink dimensions (fin diameter, fin length and fins arrangement) have been performed with analytical model to achieve better thermal performance and minimizing the fabrication cost.

4- The chosen type of cooling system (the moist wood wool pad combined with extended area) is characterized by low cost as well as easy maintenance.

5- the characteristic of narrow range of operating temperature of the module

6- At using cooling arrangement indicates that the thermal degradation would be relatively restricted in the solar module.

\section{CONFLICT OF INTERESTS.}

- There are no conflicts of interest.

\section{References}

[1] Dupr O., Vaillon R., and Green M. A, "Experimental Assessment of Temperature Coefficient Theories for Silicon Solar Cells" IEEE Journal of Photovoltaics, VOL. 6, NO. 1, January, 2016.

[2] Nishioka, L., T. Hatayama, Y. Uraoka, T. Fuyuki, R. Hagihara, and M.- Watanabe. "Field-test Analysis of PV System Output Characteristics Focusing on Module Temperature." Solar Energy Materials \& Solar Cells 75.3/4 (2003): 665-71.Academic Search Complete. Web. 9 Aug. 2011.

[3]J.A.Gotmare, D.S.Borkar, P.R.Hatwar"Experimental Investigation Of Pv Panel With Fin Cooling Under Natural Convection" International Journal of Advanced Technology in Engineering and Science, Volume No.03, Special Issue No. 02, February ISSN (online): 2348 - 7550, 2015.

[4]Cuce E, Bali T, Sekucoglu SA. "Effects of passive cooling on performance of silicon photovoltaic cells.” International Journal of Low-CarbonTechnologies;, p. 1-10,2011.

[5]Cătălin George Popovici, Sebastian ValeriuHudișteanu, Theodor DorinMateescu, NeluCristianCherecheș "Efficiency improvement of photovoltaic panels by using air cooled heat sinks" Energy Procedia 85425 - 432,2016.

[6]M.Chandrasekar, S. Suresh, T. Senthilkumar, M. Ganesh karthikeyan "Passive cooling of standalone flat PV module with cotton wick structures" Energy Conversion and Management 71, 43-50, 2013.

[7] M. Mohamed Musthafa. "Enhancing Photoelectric Conversion Efficiency of Solar Panel by Water Cooling” J Fundam Renewable Energy Appl Volume 5 • Issue 4•1000166 ISSN: 2090-4541 JFRA, an open access journal, 2015.

[8] Hasan, M.A. and Sumathy, K "Photovoltaic Thermal Module Concepts and Their Performance Analysis-A Review." Renewable and SustainableEnergyReviews, 14, 18451859. http://dx.doi.org/10.1016/j.rser.2010.03.011,2017.

[9] Corominas J. G. "Heat Sink Analytical Modeling" Master thesis, Department of Electrical Engineering and Energy Systems Higher School of Electricity, SUPELEC, France,2011.

[10]Royne, A., Dey, C. J., and Mills, D. R. "Cooling of photovoltaic cells under concentrated illumination: a critical review” Solar Energy Material \& Solar Cells, 86, 451-483, 2005. 
[11] Tonui J.K., Tripanagnostopoulos Y., "Improved PV/T solar collectors with heat extraction by forced or natural air circulation” Renewable Energy 32 pp 623-637, 2007.

[12] Brinkworth B.J. and Sandberg M. “ Design procedure for cooling ducts to minimise efficiency loss due to temperature rise in PV arrays" Solar Energy 80 pp 89-103, 2006.

[13] Corominas J. G., "Heat Sink Analytical Modeling" Master thesis, Department of Electrical Engineering and Energy Systems Higher School of Electricity, SUPELEC, France, 2011.

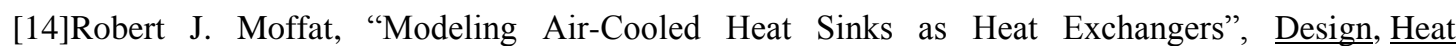
$\underline{\text { Pipes, }}$ Number 1, Test \& MeasurementHeat Exchanger, Heat Pump, Model, February, 2008 .

[15] H. Nabati, "Optimal Pin Fin Heat Exchanger Surface”, Msc Thesis, No 88 School of Sustainable Development of Society and Technology. Malardalen University, Sweden, 2008.

[16]H. Shaukatullah, W. R. Storr, B. J. Hansen, M.A. Gaynes, "Design and optimization of pin fin heat sinks for low velocity applications”, 12th IEEE SEMI-THERM Symposium, pp.151-163, 1996.

[17] Chyu, M. K., "Heat Transfer and Pressure Drop for Short Pin-Fin ArraysWith Pin-Endwall," ASME Journal of Heat Transfer, Vol. 112, pp. 926-932, 1990.

[18]S. Armstrong, W.G. Hurley,“A thermal model for photovoltaic panels under varying atmospheric conditions" Applied Thermal Engineering 30, 1488e1495, 2010.

[19] A.Q. Jakhrani, A.K. Othman, A.R.H. Rigit and S.R. Samo. "Comparison of Solar Photovoltaic Module Temperature Models” World Appl. Sci. J., 14 (Special Issue of Food and Environment), 2011.

[20] F.P. Incropera, D.P. DeWitt, Fundamentals of Heat and Mass Transfer. John Wiley \& Sons, 2002. 
تأثير التبريد التبخيري جنبا إلى جنب مع بالوعة الحرارة على أداء وحدة الطاقة الثمسية

$$
\begin{aligned}
& \text { ابتسام أحمد حسن أيمان صاتح كريم ضحى عادل } \\
& \text { قسم العندسة الميكانيكية و الكهربائية، الجامعة التكنولوجية، بغداد، العراق }
\end{aligned}
$$

engduha_1990@yahoo.com dr_esk_71@yahoo.com dr_ibtisam_ahmed@yahoo.com

الخلاصة

تم استخدام مجمو عة من زعانف الاسطو انية كمنفذ حر اري مع وسادة صوف خشبية رطبة لاستخدام نظام تبريد

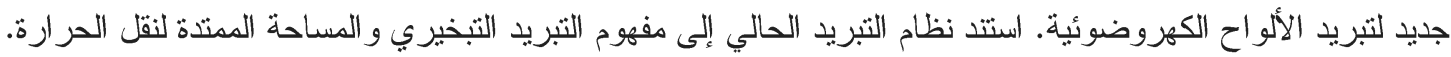

أعطت النتائج تحسينات في طاقة الخارجة وكفاءة اللوحة بنحو 32.7٪ و31.5٪ على التوالي. ويعزى هذا التحسن في أداء الوحدة إلى انخفاض درجة حرارة التشغيل للخلية الثمسية. كان الانخفاض في درجة الحرارة وحدة حو الي 26.05 الكلمات الداله: التبريد التبخيري، زعانف دبوس، سطح ممتد، دبوس الزعانف. 